\title{
The Emerging Role of 8- Isoprostane and ADMA in the Diagnosis of Diabetic Nephropathy
}

\author{
Fahmy T. Ali ${ }^{1}$, Mostafa M. ElHady ${ }^{1 *}$, Nevien A. Mahran ${ }^{2}$ and Ekrami A. Hassan ${ }^{1}$ \\ ${ }^{1}$ Department of Biochemistry, Faculty of Science, Ain Shams University, Cairo, Egypt, \\ ${ }^{2}$ Department of Clinical Pathology, Al-Hussein hospital, Al-Azhar University, Cairo, Egypt
}

\section{ARTICLE INFO}

Article history:

Received 28 September 2015

Accepted 23 November 2015

Keywords:

Diabetic nephropathy;

Microalbumin;

Oxidative stress;

8-isoprostane;

VED;

ADMA.

\begin{abstract}
A B S T R A C T
The aim of this study was to demonstrate the implication of vascular endothelial dysfunction (VED) induced by oxidative stress in the progression of diabetic nephropathy through monitoring the change of asymmetric dimethyl arginine (ADMA) and 8-isoprostane levels in patients with type 2 diabetes mellitus (T2DM) before and after the onset of nephropathy, that can be represent important biochemical evaluation with high sensitivity and specificity to make a precocious diagnosis of diabetic nephropathy (DN). ADMA and 8-isoprostane levels were estimated in a blood samples that withdrawn from diabetic patients with nephropathy before and after hemodialysis. In the same time, they were evaluated in the sera of kidney transplanted patients beside samples for diabetic patients that had no signs of clinical nephropathy as positive control and healthy subject as normal control. The results showed drastic elevation in the levels of ADMA and 8-isoprostane in the diabetic patients before and after hemodialysis sessions when compared with normal control group. In contrast, ADMA and 8isoprostane levels were improved following kidney transplantation. In the meantime, ADMA shows superior efficacy in DN diagnosis when compared to microalbumin; the gold standard for DN monitoring. Also, the sensitivity and specificity of DN diagnosis were enhanced when ADMA used in combined with microalbumin. In conclusion, there are associations between oxidative stress and the progression of vascular endothelial dysfunction that induce DN and hence ADMA and 8-isoprostane could be used as a useful promising biomarker for early detection of diabetic nephropathy.
\end{abstract}

\section{Introduction}

The rapidly increasing prevalence of diabetes mellitus has become a major global health issue. This has been, in large part, driven by the escalating epidemic of metabolic syndrome and obesity. It is projected that the number of people with diabetes worldwide will increase from 382 million in 2013 to 592 million by 2035 , according to the International Diabetes Federation ${ }^{[1]}$. Diabetic nephropathy (DN) is one of the most devastating complications of diabetes and the leading single cause of end-stage kidney disease. It accounts for a significant increase in morbidity and mortality in patients with diabetes, underscoring the importance of therapeutic interventions directed at preventing the development and progression of diabetic kidney disease [2].

* Corresponding author.

E-mail address: m_elhady@sci.asu.edu.eg
In view of its significance, there is an urgent and paramount need for proper managements that could either deter or slow the progression of diabetic nephropathy.

Increased glomerular permeability to proteins is a characteristic feature of the complication and albuminuria is a well-established clinical biomarker of DN. However, recent studies have shown that albuminuria is a less precise predictor of overt nephropathy risk than originally thought and the clinical relevance of albuminuria as a surrogate outcome in chronic kidney disease (CKD) has not been confirmed. In addition, a substantial percentage of diabetic patients develops CKD, while remaining normoalbuminuric, and reliable biomarkers are lacking in this subset of patients. There is thus increasing quest to find novel clinical biomarkers, other than albuminuria, to identify individuals at risk of DN both onset and progression ${ }^{[3]}$. 
Recently, endothelial dysfunction has been commonly found in subjects with DN, and is considered the central pathophysiologic denominator for all cardiovascular complications of diabetes. In animal models of CKD and arteriosclerosis, blocking endothelial NO leads to an increase in microvascular disease, known to impair renal autoregulation ${ }^{[4]}$.

Endothelial dysfunction due to reduced availability of nitric oxide (NO) is an early step in the course of atherosclerotic vascular disease. NO is synthesized from the amino acid L-arginine by the action of the NO synthase (NOS). Nitric oxide (NO) is a very active, but short living, that is released in the circulation from endothelial cells. It is a potent vasodilator that regulates vascular resistance and tissue blood flow. Hence, endothelial dysfunction, due to reduced NO availability is an early step of vascular disease ${ }^{[5]}$.

ADMA is released after posttranslational methylation from nuclear proteins involved in RNA processing and transcriptional control. The enzyme protein arginine methyltransferase type I (PRMT I) forms ADMA. A number of cell types, including human endothelial cells, elaborate ADMA. The substance is excreted by renal route to some extent, but the major metabolic pathway is degradation by the enzyme dimethylarginine dimethylamino-hydrolase (DDAH), which hydrolyzes ADMA to dimethylamine and L-citrulline ${ }^{[6]}$.

In clinical studies, a strong correlation between increased ADMA blood levels and impaired endothelialdependent vasodilatation, and cardiovascular morbidity and mortality has been documented in different populations, including in patients with renal disease. Thus, ADMA seems to be the culprit, and not just an innocent biochemical bystander, of the vascular endothelial dysfunction process ${ }^{[7]}$.

Oxidative stress is well recognized as an important causative factor in the development of DN. Hyperglycemia and the diabetic milieu induce cellular superoxide overproduction and the activation of pathways associated with the pathogenesis of diabetes complications ${ }^{[8]}$.

The isoprostanes (IsoPs) are a unique series of prostaglandin-like compounds formed in vivo via the non-enzymatic free radical-initiated peroxidation of arachidonic acid, a ubiquitous polyunsaturated fatty acid (PUFA). Since the discovery of these molecules over 20 years ago, one class of IsoPs, the F2-IsoPs, has become the biomarker of choice for assessing endogenous oxidative stress because these molecules are chemically stable and have been detected in all biological fluids and tissues analyzed ${ }^{[9]}$.

Oxidative stress is connected to all the important processes involved in the development of diabetic nephropathy. This is why the defense against oxidative stress is very important in disease pathogenic. In mammals, glutathione peroxidase family (GPX) is the main system of antioxidative defense. Glutathione peroxidases (GPx) are a family of selenocysteinecontaining enzymes that participate in the second step of the antioxidant pathway, which involves the neutralization of hydrogen peroxide to water utilizing glutathione (GSH) as its substrate ${ }^{[10]}$. Indeed, preclinical and clinical data have shown that GPx plays a critical role in protecting the cardiovascular system against oxidative stress with low levels of GPx activity acknowledged as an independent risk factor for cardiovascular events ${ }^{[11]}$.

Therefore, the line of this research intended to evaluate the role of vascular endothelial dysfunction induced by oxidative stress in the progression of diabetic nephropathy through identification of potential biomarkers which may be implicated in the disease. In the meantime, these markers compared with familiar markers that serve as the benchmarks of diabetic nephropathy.

\section{Subjects and methods \\ Subjects}

The study is a piolet search to check for the implication of oxidative stress and dysfunction of endothelium in the development of nephropathy in diabetic patients attending Al-Hussein hospital, Al-Azhar University, Cairo, Egypt. The protocol was conducted in accordance with guidelines approved by local research ethics committee. All subjects in this study were matched in regard to sex and age and informed consent was obtained from all the patients and volunteers. Patients with Liver disease, Bronchial asthma, Diabetes Insipidus, Thyroid disease, Obesity, cancer, pulmonary diseases, ongoing infection or inflammatory diseases were excluded from the study.

\section{Protocol of the study}

In this study the subjects were assorted into four main groups each included 15 subjects. Group 1; included diabetic patients under conservative drug management. Group 2; represented diabetic patients with nephropathy under regular hemodialysis. This group was subdivided into: Group 2a in which samples were collected from patients before hemodialysis and Group $2 \mathbf{b}$ in which samples were collected from the same patients after compilation of hemodialysis. Group 3; comprised diabetic patients with nephropathy and undergo kidney transplantation. Group 4; covered healthy subjects as normal control.

\section{Samples collection}

All subjects were instructed to fast overnight and $10 \mathrm{ml}$ of venous blood samples were withdrawn in different vacutainer tubes. Two $\mathrm{ml}$ Lithium-heparinized blood were separated rapidly for determination of glutathione peroxidase and two ml of blood was collected on EDTA coated tube for estimation of $\mathrm{Hb}_{\mathrm{Alc}}$. In the meantime, the rest of blood sample was kept in clean glass tube without additives for the determination of the rest of biochemical parameters in serum. Also, urine samples were collected for the determination of microalbumin level.

\section{Biochemical analyses}

The glucose levels were determined according to the colorimetric enzymatic method described by Trinder ${ }^{[12]}$. Total cholesterol, LDL cholesterol and HDL choles- 
terol were estimated by cholesterol oxidase peroxidase method [13]. The serum triglyceride was estimated according to method of Young and Pestaner ${ }^{[14]}$. Urea and creatinine concentrations were measured colorimetrically according to methods of Kaplan ${ }^{[15]}$ and Butler ${ }^{[16]}$ respectively. Glycated hemoglobin $(\mathrm{Hb}$ A1c) was determined using the ion exchange resin according to method described by Trivelli ${ }^{[17]}$. Urinary albumin was determined according to method of Schosinsky ${ }^{[18]}$. Nitric oxide was determined in serum according to the method of Miranda et al. ${ }^{[19]}$. Enzymatic activity of glutathione peroxidase in plasma was estimated by method described by Paglia and Valentine ${ }^{[20]}$. The level of 8 isoprostane and ADMA were determined by commercial ELISA (Cayman Chemical, USA) according to instruction included in the kits.

\section{Data presentation and statistical analysis}

Data were expressed as mean \pm S.D. results of biochemical studies were statistically analyzed using one way analysis of variance (ANOVA). All statistics were done using SPSS 17 for windows. Differences were considered statistically significant at $p<0.05$. Computing the correlation matrix of different measured parameters was also calculated. Receiver operating characteristic curves were plotted to define the optimal cut-off values and to identify the sensitivity and specificity of the targeted markers.

\section{Results:}

In comparison to the normal control group, there are significant increases in the serum levels of fasting and postprandial glucose, and glycated hemoglobin in all studied groups $(\mathrm{p}<0.001)$ as shown in Table (1). In the same line, creatinine, blood urea nitrogen and microalbumin were highly significant increased in groups 1, 2a and 2b. But, the same parameters in group 3 were recorded with non-significant changes when compared with those levels in control group (Figures 1 and 2).

Data presented in Table (2) revealed that, drastic increase $(p<0.001)$ in cholesterol and LDL-c, VLDL-c and TAG levels in groups $1,2 \mathrm{a}, 2 \mathrm{~b}$ and 3 when compared with control group. In contrast, HDL-c was significant decreased $(\mathrm{p}<0.05)$ in groups 1 and $2 \mathrm{a}$ by $6.26 \%$ and $7.34 \%$ respectively and highly significantly decreased $(\mathrm{p}<0.001)$ in group $2 \mathrm{~b}$ by $10.47 \%$. While there was a non-significant increase in group 3 by $5.57 \%$ when compared with control group.

Results of Table (3) clearly indicated that, the level of 8 -Isoprostane was highly significant increase $(\mathrm{p}<0.001)$ in group 1, 2a, 2b and 3 by $388.77 \%, 465.22 \%, 435.33 \%$ and $150.82 \%$ respectively when compared with control group. In contrast, there are highly significant decrease in plasma GSHPx activity in group 1, 2a, 2b and 3 by $59.59 \%, 66.34 \%, 68.75 \%$ and $39.26 \%$ respectively when compared with control group.

The same approach was found in the presented data where, the ADMA level was highly significant increase $(\mathrm{p}<0.001)$ in group $2 \mathrm{a} \& 2 \mathrm{~b}$ by $51.09 \%$ and $47.18 \%$ respectively. In the meantime, there was a significant increase $(\mathrm{p}<0.01)$ in group 1 by $26.26 \%$. While, it was non-significantly increased by $10.34 \%$ in groups 3 were observed when compared with control group. With the contrary that confirm these results, $\mathrm{NO}^{*}$ was highly significant decrease $(\mathrm{p}<0.001)$ in groups $1,2 \mathrm{a}$ and $2 \mathrm{~b}$ by $40.76 \%, 57.57 \%$ and $58.97 \%$ respectively. In contract, in group 3 it was non-significantly decreased by $2 \%$ when compared with control group.

Table 1: Statistical analysis of blood sugar levels and glycated hemoglobin ratio between patients and control groups.

\begin{tabular}{|c|c|c|c|}
\hline $\begin{array}{l}\text { Rarameters } \\
\text { Groups }\end{array}$ & $\begin{array}{l}\text { Fasting blood } \\
\text { sugar }(\mathbf{m g} \%)\end{array}$ & $\begin{array}{l}\text { Postprandial blood } \\
\text { sugar }(\mathrm{mg} \%)\end{array}$ & $\begin{array}{c}\mathbf{H b}_{\mathrm{A1c}} \text { ratio } \\
(\%)\end{array}$ \\
\hline $\begin{array}{l}\text { Group 1: } \\
\quad \text { Range } \\
\text { mean } \pm \text { S.D } \\
P<\end{array}$ & $\begin{array}{c}149-232 \\
179.47 \pm 22.98 \\
0.001\end{array}$ & $\begin{array}{c}196-261 \\
243.93 \pm 16.35 \\
0.001\end{array}$ & $\begin{array}{c}6.5-10.1 \\
8.15 \pm 1.04 \\
0.001\end{array}$ \\
\hline $\begin{array}{l}\text { Group 2a } \\
\text { Range } \\
\text { mean } \pm \text { S.D } \\
P< \\
\end{array}$ & $\begin{array}{c}120-249 \\
193.49 \pm 30.19 \\
0.001\end{array}$ & $\begin{array}{c}198-350 \\
261.93 \pm 42.31 \\
0.001\end{array}$ & $\begin{array}{c}7.5-13.9 \\
10.65 \pm 1.6 \\
0.001\end{array}$ \\
\hline $\begin{array}{l}\text { Group 2b } \\
\quad \text { Range } \\
\text { mean } \pm \text { S.D } \\
P<\end{array}$ & $\begin{array}{c}129-244 \\
195.17 \pm 30.7 \\
0.001\end{array}$ & $\begin{array}{c}193.8-316 \\
249.1 \pm 32.62 \\
0.001\end{array}$ & $\begin{array}{c}6.5-12.3 \\
9.99 \pm 1.59 \\
0.001\end{array}$ \\
\hline $\begin{array}{l}\text { Group } 3 \\
\text { Range } \\
\text { mean } \pm \text { S.D } \\
P<\end{array}$ & $\begin{array}{c}121-189 \\
159.1 \pm 18.73 \\
0.001\end{array}$ & $\begin{array}{c}200-270 \\
222.8 \pm 18.42 \\
0.001\end{array}$ & $\begin{array}{c}5.5-7.3 \\
6.67 \pm 0.57 \\
0.001\end{array}$ \\
\hline $\begin{array}{l}\text { Group } 4 \\
\quad \text { Range } \\
\text { mean } \pm \text { S.D }\end{array}$ & $\begin{array}{c}82-110 \\
96.6 \pm 8.5\end{array}$ & $\begin{array}{c}112-146 \\
122 \pm 9.73\end{array}$ & $\begin{array}{c}4.1-5.3 \\
4.7 \pm 0.35\end{array}$ \\
\hline
\end{tabular}




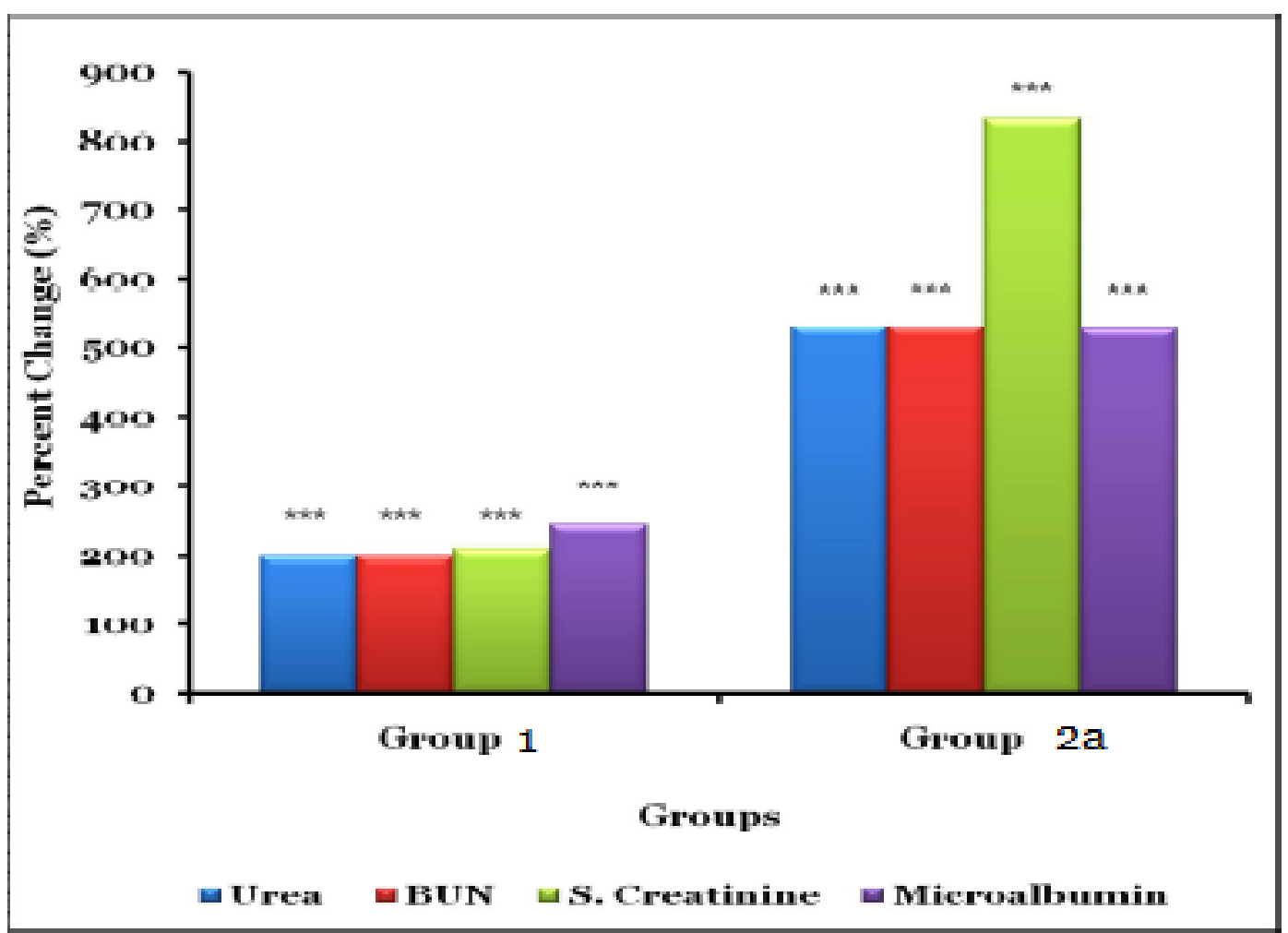

Fig 1: Percent change of urea, BUN, crteatinine and microalbumin in groups 1 and 2a compared with normal control.

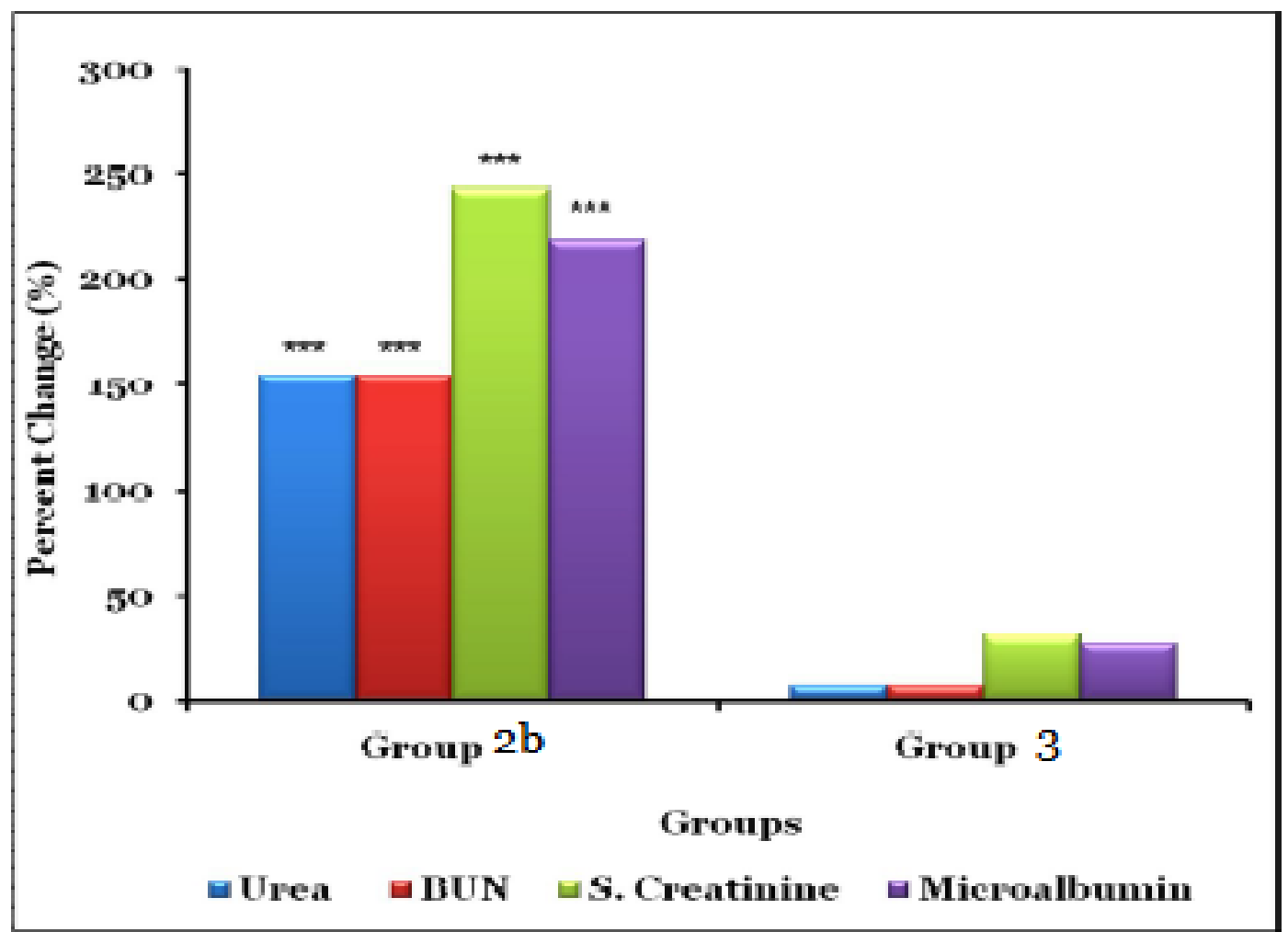

Fig 2: Percent change of urea, BUN, crteatinine and microalbumin in groups $2 \mathrm{~b}$ and 3 compared with normal control. 
Table 2: Statistical analysis of lipid profile parameters between patients and control groups.

\begin{tabular}{|c|c|c|c|c|c|}
\hline $\begin{array}{l}\text { Parameters } \\
\text { Groups }\end{array}$ & $\begin{array}{c}\text { TC } \\
(\mathrm{mg} \%)\end{array}$ & $\begin{array}{l}\text { HDL-c } \\
(\mathrm{mg} \%)\end{array}$ & $\begin{array}{l}\text { LDL-c } \\
(\mathrm{mg} \%)\end{array}$ & $\begin{array}{l}\text { VLDL-c } \\
(\mathrm{mg} \%)\end{array}$ & $\begin{array}{c}\text { TAG } \\
(\mathrm{mg} \%)\end{array}$ \\
\hline $\begin{array}{l}\text { Group 1: } \\
\text { Range } \\
\text { mean } \pm \text { S.D } \\
P<\end{array}$ & $\begin{array}{c}199-272 \\
222.23 \pm 22.3 \\
0.001\end{array}$ & $\begin{array}{c}32-38.9 \\
35.34 \pm 2.34 \\
0.05\end{array}$ & $\begin{array}{c}120.2-198.6 \\
149.19 \pm 22.8 \\
0.001\end{array}$ & $\begin{array}{c}33.6-42 \\
37.69 \pm 2.4 \\
0.001\end{array}$ & $\begin{array}{c}168-210.2 \\
188.47 \pm 12.1 \\
0.001\end{array}$ \\
\hline $\begin{array}{l}\text { Group 2a } \\
\text { Range } \\
\text { mean } \pm \text { S.D } \\
P< \\
\end{array}$ & $\begin{array}{c}180-272 \\
226.45 \pm 29.4 \\
0.001\end{array}$ & $\begin{array}{c}31-40.6 \\
34.93 \pm 2.7 \\
0.05\end{array}$ & $\begin{array}{c}100.1-200.8 \\
148.59 \pm 30.46 \\
0.001\end{array}$ & $\begin{array}{c}37.2-53.7 \\
42.9 \pm 5.2 \\
0.001\end{array}$ & $\begin{array}{c}186-268.8 \\
214.63 \pm 26.4 \\
0.001\end{array}$ \\
\hline $\begin{array}{l}\text { Group 2b } \\
\text { Range } \\
\text { mean } \pm \text { S.D } \\
P<\end{array}$ & $\begin{array}{c}71-273.3 \\
234.45 \pm 34.4 \\
0.001\end{array}$ & $\begin{array}{c}30-39.2 \\
33.75 \pm 2.8 \\
0.001\end{array}$ & $\begin{array}{c}100.3-199.6 \\
154.79 \pm 30.9 \\
0.001\end{array}$ & $\begin{array}{c}34.5-57.5 \\
46.43 \pm 7.6 \\
0.001 \\
\end{array}$ & $\begin{array}{c}172-287.7 \\
232.13 \pm 38.2 \\
0.001\end{array}$ \\
\hline $\begin{array}{l}\text { Group } 3 \\
\text { Range } \\
\text { mean } \pm \text { S.D } \\
P<\end{array}$ & $\begin{array}{c}71-273.3 \\
200.13 \pm 19.9 \\
0.001\end{array}$ & $\begin{array}{c}33.6-46 \\
39.8 \pm 3.42 \\
\mathrm{NS} \\
\end{array}$ & $\begin{array}{c}97.92-156.7 \\
122.57 \pm 17.9 \\
0.01\end{array}$ & $\begin{array}{c}32.2-43.3 \\
37.76 \pm 3.6 \\
0.001 \\
\end{array}$ & $\begin{array}{c}161-216.5 \\
188.79 \pm 18.3 \\
0.001\end{array}$ \\
\hline $\begin{array}{l}\text { Group } 4 \\
\text { Range } \\
\text { mean } \pm \text { S.D } \\
\end{array}$ & $\begin{array}{c}122-196 \\
149.78 \pm 20.6 \\
\end{array}$ & $\begin{array}{c}32-41.2 \\
37.7 \pm 2.67\end{array}$ & $\begin{array}{c}66.2-130 \\
89.84 \pm 19.6\end{array}$ & $\begin{array}{c}19.1-24.6 \\
22.24 \pm 1.9 \\
\end{array}$ & $\begin{array}{c}95.8-123 \\
111.19 \pm 9.5 \\
\end{array}$ \\
\hline
\end{tabular}

Table 3: Statistical analysis of ADMA, NO, 8-isoprostane and Pl. GSHPX between patients groups and control groups.

\begin{tabular}{|c|c|c|c|c|}
\hline \multirow{2}{*}{$\begin{array}{l}\text { Parameters } \\
\text { Groups }\end{array}$} & ADMA & NO & \multirow{2}{*}{$\begin{array}{c}\text { 8-Isoprostane } \\
\mathrm{pg} / \mathrm{ml}\end{array}$} & \multirow{2}{*}{$\begin{array}{c}\text { Pl. GSHPx } \\
\mathrm{mU} / \mathrm{ml}\end{array}$} \\
\hline & \multicolumn{2}{|c|}{$\mu \mathrm{mole} / \mathrm{L}$} & & \\
\hline $\begin{array}{l}\text { Group 1: } \\
\text { Range } \\
\text { mean } \pm \text { S.D } \\
P<\end{array}$ & $\begin{array}{c}0.61-0.84 \\
0.73 \pm 0.07 \\
0.01\end{array}$ & $\begin{array}{c}22.3-32.4 \\
27.37 \pm 3.01 \\
0.001 \\
\end{array}$ & $\begin{array}{c}280-430 \\
359.73 \pm 45.97 \\
0.001 \\
\end{array}$ & $\begin{array}{c}38-101.3 \\
81.63 \pm 16.86 \\
0.001 \\
\end{array}$ \\
\hline $\begin{array}{l}\text { Group 2a } \\
\quad \text { Range } \\
\text { mean } \pm \text { S.D } \\
P<\end{array}$ & $\begin{array}{c}0.68-1.2 \\
0.87 \pm 0.15 \\
0.001\end{array}$ & $\begin{array}{c}16.3-21.5 \\
18.96 \pm 1.32 \\
0.001\end{array}$ & $\begin{array}{c}340-460 \\
416 \pm 39.35 \\
0.001\end{array}$ & $\begin{array}{c}44-86.3 \\
67.99 \pm 12.51 \\
0.001\end{array}$ \\
\hline $\begin{array}{l}\text { Group 2b } \\
\text { Range } \\
\text { mean } \pm \text { S.D } \\
P<\end{array}$ & $\begin{array}{c}0.67-1.2 \\
0.85 \pm 0.14 \\
0.001\end{array}$ & $\begin{array}{c}16.9-23.5 \\
19.61 \pm 2.05 \\
0.001\end{array}$ & $\begin{array}{c}321-473 \\
394 \pm 61.02 \\
0.001\end{array}$ & $\begin{array}{c}47-80.1 \\
63.14 \pm 10.63 \\
0.001\end{array}$ \\
\hline $\begin{array}{l}\text { Group } 3 \\
\text { Range } \\
\text { mean } \pm \text { S.D } \\
P<\end{array}$ & $\begin{array}{c}0.41-0.68 \\
0.64 \pm 0.09 \\
\text { NS }\end{array}$ & $\begin{array}{c}39.2-48.6 \\
45.19 \pm 2.61 \\
\mathrm{NS}\end{array}$ & $\begin{array}{c}145-230 \\
184.6 \pm 26.15 \\
0.001\end{array}$ & $\begin{array}{c}76.9-198 \\
122.72 \pm 43.43 \\
0.001\end{array}$ \\
\hline $\begin{array}{l}\text { Group } 4 \\
\text { Range } \\
\text { mean } \pm \text { S.D }\end{array}$ & $\begin{array}{c}0.52-0.68 \\
0.58 \pm 0.06\end{array}$ & $\begin{array}{c}38.6-50.4 \\
46.21 \pm 3.4\end{array}$ & $\begin{array}{c}44-98 \\
73.6 \pm 15.94\end{array}$ & $\begin{array}{c}156-232 \\
202.03 \pm 23.17\end{array}$ \\
\hline
\end{tabular}

The results of computing the correlation matrix of the different measured parameters and either ADMA, NO', pl. GSHPX and 8-isoprostane that shown in Table (4) illustrated a highly significant positive correlation was shown between 8 -isoprostane and $\mathrm{Hb}_{\mathrm{A} 1 \mathrm{c}}$, ADMA \& creatinine and 8-isoprostane \& creatinine in group $2 \mathrm{a}$.
In the mean time, a highly significant negative correlation was shown between ADMA and nitric oxide in group $2 \mathrm{~b}$.

Meanwhile, in group 3; there is a highly significant positive correlation was shown between 8-isoprostane \& $\mathrm{Hb}_{\mathrm{Alc}}$ as shown in Figure (3). 
Table 4: Correlation between targeted parameters in diabetic nephropathy groups.

\begin{tabular}{|l|l|c|c|c|}
\hline Group & \multicolumn{1}{|c|}{ Correlation } & r & $\mathbf{r}^{2}$ & $\boldsymbol{P}<$ \\
\hline \multirow{3}{*}{ Gr 2a } & 8-isoprostane \& HbA1c & 0.557 & 0.31 & 0.05 \\
\cline { 2 - 5 } & 8-isoprostane \& creatinine & 0.661 & 0.437 & 0.05 \\
\cline { 2 - 5 } & ADMA \& creatinine & 0.952 & 0.906 & 0.001 \\
\cline { 2 - 5 } & ADMA \& nitric oxide & -0.965 & 0.931 & 0.001 \\
\hline Gr 2b & ADMA \& nitric oxide & -0.971 & 0.942 & 0.001 \\
\hline
\end{tabular}

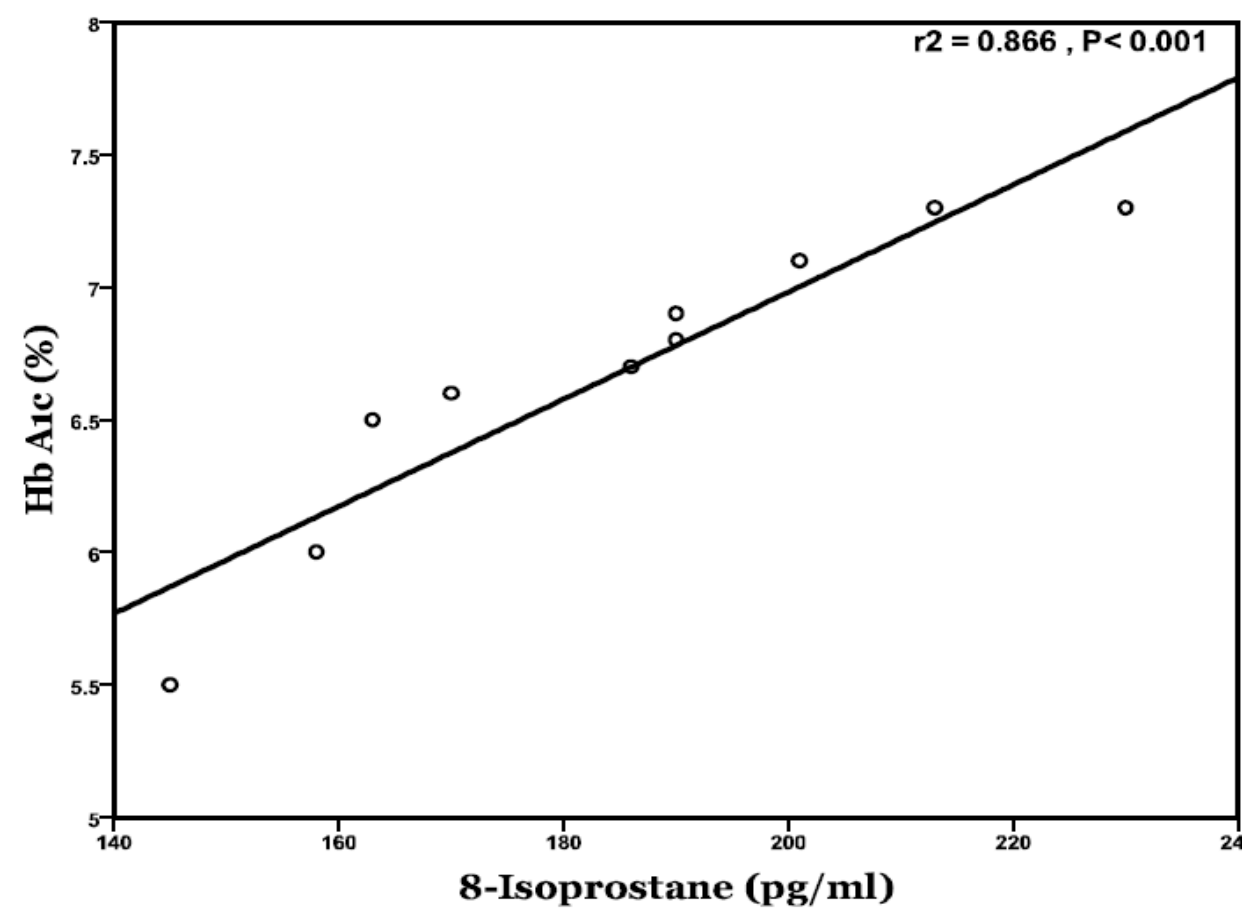

Fig 3: Correlation between 8-isoprostane $\& \mathrm{Hb}_{\mathrm{Alc}}$ in kidney transplanted group (group 3).

The results presented in Figure (4) showed the receiveroperator curve (ROC) of targeted parameters where the area under curve (AUROC) of 8-isoprostane for the diagnosis of DN was 0.838 , which was superior to that of microalbumin (0.740) but inferior to ADMA (0.945). The DN diagnostic sensitivities of microalbumin, 8isoprostane and ADMA in the serum samples were $80.1 \%, 73.6 \%$ and $85.4 \%$ and specificities were $85 \%$, $76 \%$ and $90 \%$ at cut-offs of $84.07 \mu \mathrm{g} / \mathrm{ml}, 343.5 \mathrm{pg} / \mathrm{ml}$ and $0.70 \mu$ mole/L respectively. However, when ADMA used in combination with microalbumin for early detection of DN, they increased sensitivity up to $90.3 \%$, whereas, specificity was $94 \%$ Table (5).

\section{Discussion}

Diabetic nephropathy (DN) is a serious microvascular complication of T2DM that may eventually require dialysis, and it represents a major cause of cardiovascular mortality ${ }^{[21]}$. Approximately one-third of patients with diabetes eventually developed DN, so it is critical to identify the risk factors for DN in T2DM ${ }^{[22]}$. Although hyperglycemia is necessary, it is not a suffi- cient condition to cause DN because some patients with diabetes with excellent blood glucose control still develop DN, whereas others with poor blood glucose control can escape from this renal complication during the first two decades of diabetes. Therefore, a genetic susceptibility to DN has been proposed ${ }^{[23]}$.

The present study was carried out in attempt to evaluate the potential link between oxidative stress that induce VED and pathogenesis of diabetic nephropathy in Egyptian patients suffering from T2DM.

Current study showed that, there was significant increase in ADMA level in DN, pre-hemodialysis \& posthemodialysis groups when compared to control group. This is explained by Lin et al ${ }^{[24]}$ who reported that, hyperglycemia impairs DDAHs activity in vascular smooth muscle cells and the endothelium, thereby contributing to elevated ADMA levels among diabetic patients.

In the meantime, the present results show that there was a non-significant decrease in ADMA level in posthemodialyzed group compared to pre-hemodialyzed 


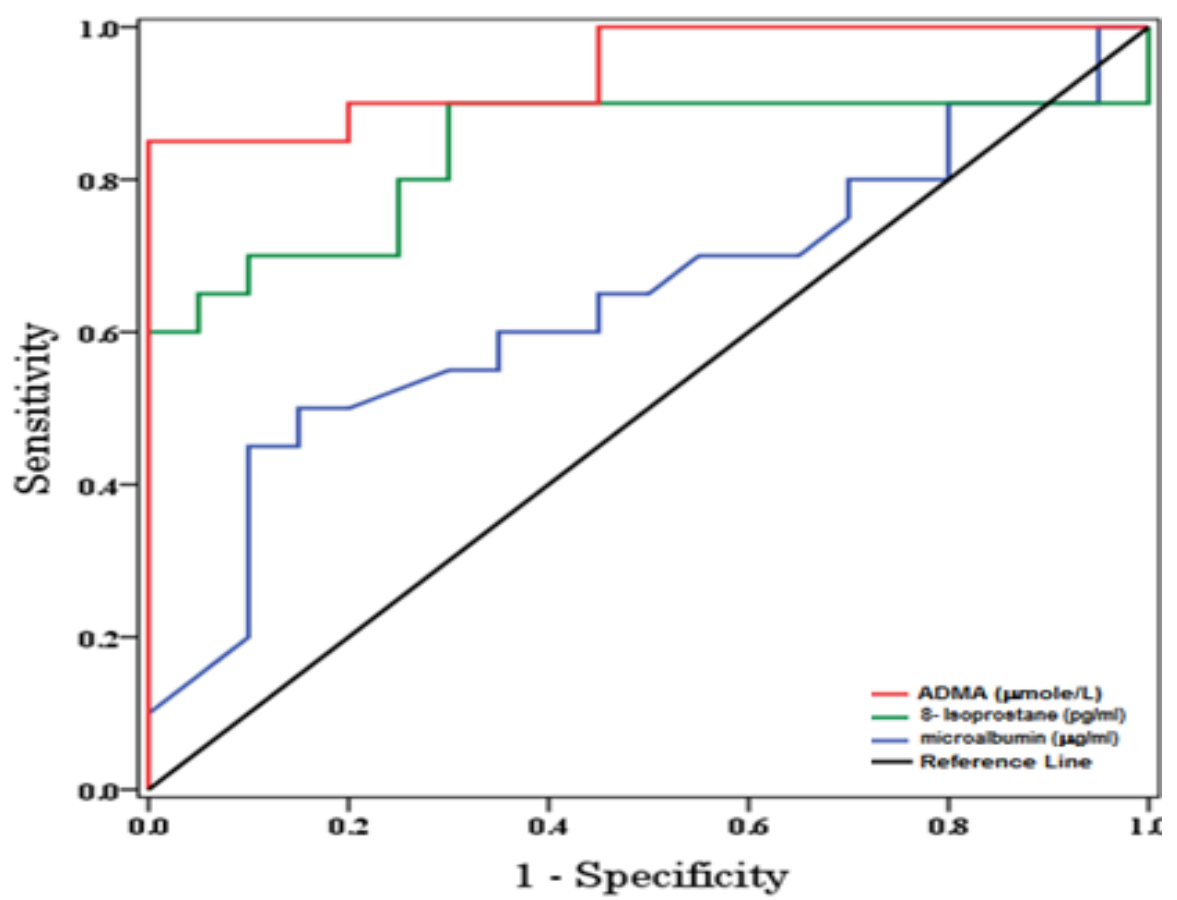

Fig 4: Receiver operating characteristic (ROC) curves display of microalbumin, 8- Isoprostane \& ADMA for DN patients group.

Table 5: Sensitivity and specificity of targeted markers for early diagnosis of Diabetic nephropathy.

\begin{tabular}{|l|c|c|c|}
\hline \multicolumn{1}{|c|}{ Variable } & Cut-off value & Sensitivity & Specificity \\
\hline Microalbumin $(\mu \mathrm{g} / \mathrm{ml})$ & 84.07 & $80.1 \%$ & $85 \%$ \\
\hline 8- isoprostane $(\mathbf{p g} / \mathrm{ml})$ & 343.5 & $73.6 \%$ & $76 \%$ \\
\hline ADMA $(\mu \mathrm{mole} / \mathrm{L})$ & 0.70 & $85.4 \%$ & $90 \%$ \\
\hline $\begin{array}{l}\text { Combined microalbumin } \\
\text { and ADMA }\end{array}$ & $\begin{array}{c}84.07 \mu \mathrm{g} / \mathrm{ml} \\
0.70 \mu \mathrm{mole} / \mathrm{L}\end{array}$ & $90.3 \%$ & $94 \%$ \\
\hline
\end{tabular}

group. This was in agreement with Kielstein et al. $^{[25]}$ who show that; at $5 \mathrm{hr}$ after the hemodialysis session, ADMA level was decreased by $65 \%$, compared to $1 \mathrm{hr}$ after dialysis.

The results showed that, ADMA level was decreased after renal transplantation, compared to hemodialysis groups, but it was still elevated when compared to control group. These results are agreement with Yilmaz et al. [26] who declared that after successful renal transplantation; ADMA levels rapidly declined over 28 days after transplantation and were associated with an improvement in endothelial function.

Endothelial-derived nitric oxide (EDNO), a potent gaseous mediator released by endothelial cells, is widely accepted as the key determinant of endothelial function.

The obtained results of decreased NO level are in agreement with Kimura $\boldsymbol{e t}$ al. ${ }^{[27]}$ who reported that The NO output is decreased in end-stage renal disease (ESRD) patients on both peritoneal dialysis (PD) and hemodialysis (HD) as well as in CKD patients. Using the more direct approach to measure the ${ }^{15} \mathrm{~N}_{2}$-labeled arginine-to-citrulline conversion, Wever et al. ${ }^{[28]}$ also concluded that NO production was decreased in humans with CKD. This can be explained as; DM induce reactive oxygen species overproduction which result in scavenging of $\mathrm{NO}$, resulting in decreased nitric oxide bioavailability causing endothelial dysfunction seen in DM.

The most acceptable explanation for the cumulative obtained results is inhibition of NO synthase via ADMA which is a competitive inhibitor of L-Arginine; the substrate of NOS. This is lead to decreased production of NO. In the same context, the results that shown an elevation of NO level in transplanted group compared to other groups was not surprising because the same group has the lowest ADMA level compared to all patient groups.

The level of isoprostane (IsoP) in blood or urine is widely regarded as the reference marker for the assessment of oxidative stress. As a result, nowadays, Isoprostane is the most frequently measured oxidative stress marker Nikolaidis et al. ${ }^{[29]}$. Its level had advantages over other quantitative markers of oxidative stress: they are chemically stable, specific products of 
lipid peroxidation; they are formed in vivo and are present in all normal tissues and biological fluids Milne et al. ${ }^{[30]}$.

In the present study, the level of 8-isoprostane was high significantly increased in all patients groups. These results are in line with Choi et al. ${ }^{[31]}$ who illustrate these observations as oxidative stress is increased in Type 2 diabetes and this appears to underlie the development of diabetic complications. Increased oxidative stress is claimed to be triggered directly by hyperglycemia.

Glutathione peroxidase, a Selenium containing enzyme, is a key component in an enzymatic system that is most responsible for controlling cellular peroxide levels.

In this study, Pl-GSHPx was found to be highly significantly decreased in all groups when compared with normal control. The results arein harmony with results of El-Far et al. ${ }^{[32]}$, Roxborough et al. ${ }^{[33]}$ and Zachara et al. ${ }^{[34]}$.

These results can be illustrated by the fact that the main source of the antioxidant in the human body is located in human proximal tubules. In the meantime, the endogenous, toxic compounds in the blood, which exert an inhibitory effect on this enzyme, are responsible for the decrease in GSH-Px activity. During dialysis, these compounds are removed so that the enzyme activity is enhanced.

From the aforementioned results it can concluded that; ADMA, the masked culprit implicated in the development of vascular endothelial dysfunction, inhibit eNOS resulting in decreased NO production and hence, the development of diabetic nephropathy in diabetic patients. Also, 8-isoprostane is a very unique $\&$ specific oxidative stress parameter through which, the stress degree can be defined.

Together, ADMA \& 8-isoprostane can be considered to be good prognostic biomarkers of vascular endothelial dysfunction which leads to diabetic nephropathy. The first, gave aware about the degree of vascular endothelial dysfunction. The second, gave knowledge about the degree of oxidative stress occurred.

\section{References}

1) Ding Y. and Choi M. (2015). Autophagy in diabetic nephropathy. Society for Endocrinology. DOI: 10.1530/JOE-14-0437.

2) Shi Y. and Hu F. (2014). The global implications of diabetes and cancer. Lancet 383: 1947-1948. (doi:10.1016/S01406736(14)60886-2).

3) Lee S. and Choi M. (2014). Urinary biomarkers for early diabetic nephropathy: beyond albuminuria. Pediatr Nephrol. DOI 10.1007/s00467-014-2888-2.

4) Sharma A., Bernatchez P. and De Haan J. (2012). Targeting endothelial dysfunction in vascular complications associated with diabetes. International journal of vascular medicine, 2012: 1-12.

5) Chen C., Wang T. and Varadharaj, S. (2011). Superoxide induces eNOS protein Thiyl radical formation: a novel mechanism regulating eNOS function and coupling. The Journal of Biological Chemistry, 286(33): 29098-29107.

6) Leiper J. and Vallance P. (2005). The synthesis and metabolism of asymmetric dimethylarginine (ADMA). European Journal of Clinical Pharmacology, 62(S1): 33-38.

7) Tayeh, O., Fahmi, A., Islam, M. and Saied, M. (2011). Asymmetric dimethylarginine as a prognostic marker for cardiovascular complications in hypertensive patients. The Egyptian Heart Journal, 63(2): 117-124.

8) Drobiova, H., Thomson, M., Al-Qattan, K., Peltonen-Shalaby, R., Al-Amin, Z. and Ali, M. (2011). Garlic Increases Antioxidant Levels in Diabetic and Hypertensive Rats Determined by a Modified Peroxidase Method. Evidence-based complementary and alternative medicine : eCAM, 2011:1-9.

9) Jahn, U., Galano, J. and Durand, T. (2008). Beyond prostaglandins-chemistry and biology of cyclic oxygenated metabolites formed by free-radical pathways from polyunsaturated fatty acids. Angew Chem Int Ed Engl., 47(32):5894-5955.

10) Panduru, M., Ion, D., Mota, M., Cimoneriu, D., Stavarachi, M., Pisoschi, C., Radu, S., Anghle, M. and Mota, E. (2011). Glutathione peroxidase 1 (GPX-1) polymorphism and diabetic nephropathy in type 1 diabetes - A preliminary study. Romanian Biotechnological Letters, 16(5):6655-6667.

11) Brigelius-Flohe, R., Banning, A. and Schnurr, K. (2003). Selenium-dependent enzymes in endothelial cell function. Antioxidants and Redox Signaling, 5(2): 205- 215.

12) Trinder, P. (1969). Determination of Glucose in Blood Using Glucose Oxidase with an Alternative Oxygen Acceptor. Ann. Clin. Biochem, 6: 24-25.

13) Friedewald, W. (1972). Determination of lipoprotein cholesterol. Clin. Chem., 18:499.

14) Young, D. and Pestaner, L. (1975). Determination of serum triacylglycerols. Clin. Chem., 21:5.

15) Kaplan, A. (1984). Quantitative determination of blood urea. Clin. Chem., 1257-1260.

16) Butler, A. (1975). The Jaffe reaction. Identification of the coloured species. Clin. Chem. Acta., 227-232.

17) Trivelli, L. (1971). Quantitative determination of whole blood glycohemoglobin A1c. New Engl. J. Med., 284:353.

18) Schosinsky, M. (1987). Determination of microalbinuria. Clin. Chem.; 223:6.

19) Miranda, K., Espey, M. and Wink D. (2001). A Rapid, Simple Spectrophotometric Method for Simultaneous Detection of Nitrate and Nitrite. Online, 5(1): 62-71.

20) Paglia, D. and Valentine, W. (1967). Studies on the quantitative and qualitative characterization of erythrocyte GSHPx. J. Lab. Clin. Med., 70: 158-169. 
21) Park, C. (2014). Diabetic Kidney Disease: From Epidemiology to Clinical Perspectives. Diabetes Metab J., 38:252-260.

22) Brown, W. (2008). Microvascular complications of diabetes mellitus: renal protection accompanies cardiovascular protection. The American Journal of Cardiology, 102(12): 10L-13L.

23) Calabrese, V., Cornelius, C., Leso, V., TrovatoSalinaro, A., Ventimiglia, B., Cavallaro, M. and Scuto, M. (2012). Oxidative stress, glutathione status, sirtuin and cellular stress response in type 2 diabetes. Biochimica et biophysica acta; 1822(5): 729-736.

24) Lin, K., Ito, A., Asagami, T., Tsao, P., Adimoolam, S., Kimoto, M., Tsuji, H., Reaven, G. and Cooke, J. (2002). Impaired nitric oxide synthase pathway in diabetes mellitus: role of asymmetric dimethylarginine and dimethylarginine dimethylamino-hydrolase. Circulation, 106:987-992.

25) Kielstein, J., Böger, R., Bode-Böger, S., Schäffer, J., Barbey, M., Koch, K. and Frölich, J. (2005). Asymmetric dimethylarginine plasma concentrations differ in patients with end-stage renal disease: relationship to treatment method and atherosclerotic disease. Journal of the American Society of Nephrology: JASN, 10(3): 594-600.

26) Yilmaz, M., Saglam, M. and Caglar, K. (2005). Endothelial functions improve with decrease in asymmetric dimethylarginine levels after renal transplantation. Transplantation, 80:1660-1666.

27) Kimura, S., Zhang, G., Nishiyama, A., Shokoji, T., Yao, L., Fan, Y., Rahman, M. and Abe, Y. (2005). Mitochondria-derived reactive oxygen species and vascular endothelial dysfunction of type II diabetes. Hypertension, 45:438-444.

28) Wever, R., Boer, P., Hijmering, M., Stroes, E., Verhaar, M., Kastelein, J., Versluis, K., Lagerwerf, F., Van Rijn, H., Koomans, H. and Rabelink T. (1999). Nitric oxide production is reduced in patients with chronic renal failure. Arterioscler Thromb Vasc Biol, 19: 1168-1172.

29) Nikolaidis, M., Kyparos, A. and Vrabas, I. (2011). F2-isoprostane formation; measurement and interpretation: the role of exercise. Prog Lipid Res., (1):89-103.

30) Milne, G., Yin H., Hardy K., Davies, S. and Roberts, L. (2011). Isoprostane generation and function. Chemical Reviews, 111(10); 5973-96.

31) Choi, W., Benzie, I., Ma, S., Strain, J. and Hannigan, B. (2008). Acute hyperglycemia and oxidative stress: Direct cause and effect? Free Radical Biology and Medicine, 44(7): 1217-1231.

32) El-Far, M., Bakr, M., Farahat, S. and Abd ElFattah, E. (2005). Glutathione peroxidase activity in patients with renal disorders. Clin. Exp. Nephrol; 9(2):127-131.

33) Roxborough, H., Mercer, C., McMaster, D., Maxwell, A. and Young, I. (1999). Plasma glutathione peroxidase activity is reduced in haemodialysis patients. Nephron, 81:278-283.

34) Zachara, B., Salak, A., Koterska, D., Manitius, J. and Wasowicz, W. (2004). Selenium and glutathione peroxidases in blood of patients with different stages of chronic renal failure. J. Trace Elem. Med. Biol., 17:291- 299. 